\title{
TINGKAT KESEGARAN JASMANI PADA SISWA/I SMP CAHAYA PENGHARAPAN ABADI LABUHAN DELI
}

\author{
Aser Paul Nainggolan
}

Universitas Quality Berastagi

Email: aserpaul@yahoo.co.id

\begin{abstract}
Abstrak
Pendidikan jasmani memiliki peran yang sangat penting dalam mengintensifkan penyelenggaraan pendidikan sebagai suatu proses pembinaan manusia yang berlangsung hidup. Pendidikan jasmani memberikan kesempatan pada siswa untuk terlibat langsung dalam aneka pengalaman belajar melalui aktifitas jasmani, bermain, dan berolahraga yang dilakukan secara sistematis, terarah dan terencana. Pembekalan pengalaman belajar melalui proses pembelajaran pendidikan jasmani dengan mengajarkan berbagai keterampilan gerak dasar, teknik, dan strategi permainan olahraga, internalisasi nilai-nilai (sportifitas, jujur kerjasama, dan lain-lain). Pendidikan di Indonesia beragam bentuk bidang studinya, salah satu diantaranya adalah pendidikan jasmani. Pendidikan jasmani dan olahraga mempunyai peranan penting dalam pembentukan manusia seutuhnya. Untuk mengetahui dan menilai tingkat kesegaran jasmani seseorang dapat dilaksanakan dengan melakukan Tes Kesegaran Jasmani Indonesia. Oleh karena itu, Tes Kesegaran Jasmani Indonesia (TKJI) sangat penting dalam pembelajaran pendidikan jasmani dan olahraga. karena dapat melihat tingkat kesegaran jasmani siswa di setiap sekolah. Jenis penelitian yang digunakan adalah penelitian kuantitatif dengan menggunakan metode deskriptif analisis. Siswa yang menjadi sampel adalah siswa putraputri kelas IX yang diambil menggunakan teknik random sampling sehingga mendapatkan 17 siswa di sekolah. Peneliti menggunakan tes TKJI dengan lima item tes yang dilakukan secara berurutan. Adapun hasil penelitian rata-rata TKJI SMP Cahaya Pengharapan Abadi adalah lari 50 meter putera rata-rata 7.10 detik dan puteri 8,08 detik. Gantung siku tekuk putera rata-rata 8 kali dan puteri 30.15 detik. Sit-Up putera rata-rata 40 kali dan puteri 28 kali. Vertical Jump putera rata-rata $40.12 \mathrm{~cm}$ dan puteri $30.10 \mathrm{~cm}$. Lari 1000 meter putera rata-rata 5 menit 51 detik dan $800 \mathrm{~m}$ puteri 5 menit 58 detik.
\end{abstract}

\section{Kata Kunci : Kesegaran Jasmani SMP Cahaya Pengharapan Abadi Labuhan Deli}

\begin{abstract}
Physical education has a very important role in intensifying the implementation of education as a process of human development that lasts life. Physical education provides opportunities for students to be directly involved in various learning experiences through physical activity, play, and exercise which is carried out systematically, directed and planned. Debriefing learning experiences through the process of learning physical education by teaching various basic motion skills, techniques, and strategies for sports games, internalizing values (sportsmanship, honest cooperation, etc.). Education in Indonesia varies in the form of its field of study, one of which is physical education. Physical education and exercise have an important role in the formation of whole people. To find out and assess the level of physical fitness of a person can be carried out by conducting an Indonesian Physical Fitness Test. Therefore, the Indonesian Physical Fitness Test (TKJI) is very important in learning physical education and sports. because it can see the level of physical fitness of students in each school. The type of research used is quantitative research using descriptive analysis methods. Students who were sampled were students of grade IX students who were taken using random sampling techniques to get 17 students in the school. The researcher used the TKJI test with five items of tests conducted sequentially. The results of the average TKJI Eternal Hope Labuhan Deli research are a 50 meter men's run, an average of 7.10 seconds and a princess of 8.08 seconds. Hang your elbows bent on an average 8 times and princess 30.15 seconds. The average male Sit-Up is 40 times and the princess is 28 times. Vertical Jump is an average son of $40.12 \mathrm{~cm}$ and the princess is $30.10 \mathrm{~cm}$. Running 1000 meters son averaged 5 minutes 51 seconds and 800 m princess 5 minutes 58 seconds.
\end{abstract}

\section{Keywords: Physical Freshness, Middle Light, Eternal Hope Labuhan Deli}

Dipublikasikan Oleh :

UPT Publikasi dan Pengelolaan Jurnal

Universitas Islam Kalimantan Muhammad Arsyad Al-Banjari Banjarmasin 


\section{PENDAHULUAN}

Memasuki abad ke-21 dunia pendidikan Indonesia dibikin heboh. Kehebohan tersebut bukan disebabkan karena kehebatan mutu pendidikan nasional tetapi lebih banyak disebabkan karena kesadaran akan bahaya keterbelakangan pendidikan di Indonesia. Hal ini bukan berarti tidak terjadi sesuatu di dalam perkembangan pendidikan nasional. Dilihat secara objektif, perkembangan itu sangat pesat apabila kita lihat misalnya dari jumlah penduduk Indonesia yang dapat mengenyam pendidikan dibandingkan dengan pada masa kolonial.

Selain itu, Pendidikan jasmani merupakan media untuk mendorong perkembangan keterampilan motorik, kemampuan fisik, pengetahuan, penalaran, penghayatan nilai (sikap, mental, emosional, spiritual, sosial), dan pembiasaam pola hidup sehat yang bermuara untuk merangsang pertumbuhan serta perkembangan yang seimbang

Pendidikan jasmani (Penjas) mempunyai peran penting untuk meningkatkan kualitas manusia. Hal ini sesuai pendapat bahwa, Pendidikan jasmani merupakan bagian dari pendidikan secara umum. Pendidikan jasmani dapat didefinisikan sebagai suatu proses pendidikan yang ditujukan untuk mencapai tujuan pendidikan melalui gerakan fisik. Pendidikan sebagai salah satu sub-sistem pendidikan yang berperan yang penting dalam mengembangkan kualitas manusia Indonesia Pendidikan jasmani, olahraga, dan kesehatan merupakan salah satu mata pelajaran yang ada di sekolah menengah pertama (SMP).

Pendidikan jasmani memiliki peran yang sangat penting dalam mengintensifkan penyelenggaraan pendidikan sebagai suatu proses pembinaan manusia yang berlangsung hidup. Pendidikan jasmani memberikan kesempatan pada siswa untuk terlibat langsung dalam aneka pengalaman belajar melalui aktifitas jasmani, bermain, dan berolahraga yang dilakukan secara sistematis, terarah dan terencana. Pembekalan pengalaman belajar melalui proses pembelajaran pendidikan jasmani dengan mengajarkan berbagai keterampilan gerak dasar, teknik, dan strategi permainan olahraga, internalisasi nilai-nilai (sportifitas, jujur kerjasama, dan lain-lain).

Pendidikan di Indonesia beragam bentuk bidang studinya, salah satu diantaranya adalah pendidikan jasmani. Pendidikan jasmani dan olahraga mempunyai peranan penting dalam pembentukan manusia seutuhnya. Untuk mengetahui dan menilai tingkat kesegaran jasmani seseorang dapat dilaksanakan dengan melakukan Tes Kesegaran Jasmani Indonesia. Oleh karena itu, Tes Kesegaran Jasmani Indonesia (TKJI) sangat penting dalam pembelajaran pendidikan jasmani dan olahraga. karena dapat melihat tingkat kesegaran jasmani siswa di setiap sekolah.

Berdasarkan hasil observasi ke beberapa SMP Cahaya Pengharapan Abadi terdapat Peneliti melakukan interviu ke guru yang mengajar pendidikan jasmani dan sekolah tersebut, ternyata dalam pembelajaran penjasorkes belum pernah melakukan Tes Kesegaran Jasmani Indonesia. Sehingga belum bisa diketahui tingkat kesegaran jasmani di Sekolah tersebut.

Melalui pembelajaran pendidikan jasmani peserta didik akan memperoleh pengalaman yang erat kaitannya dengan kesan pribadi yang menyenangkan berbagai ungkapan kreatif, inovatif, keterampilan gerak, kesegaran jasmani, pola hidup sehat, pengetahuan dan pemehaman terhadap gerak manusia, juga akan membentuk kepribadian yang positif.

Proses belajar mengajar (PMB) merupakan intekrasi berkelanjutan antara prilaku guru dan peserta didik. Dalam pelaksanaan proses belajar mengajar pendidikan jasmani keempat faktor ini tidak dapat dipisahkan satu sama lain, yaitu : tujuan, materi, metoda, dan evaluasi. Salah satu prinsip penting dalam pendidikan jasmani adakah pastisipasi peserta didik secara penuh dan merata. Oleh karena itu, guru pendidikan jasmani harus memperhatikan kepentingan setiap peserta didik.

Berdasarkan latar belakang di atas dapat diambil rumusan masalah dalam penelitian ini adalah

1) Bagaimana tingkat kesegaran jasmani siswa putra dan putri di SMP Cahaya Pengharapan Abadi?;

2) Manakah diantara siswa/i tersebut yang memiliki tingkat kesegaran jasmani yang lebih baik?;

Dari rumusan masalah penelitian yang diangkat mempunyai tujuan sebagai berikut:

1) Untuk mengetahui tingkat kesegaran jasmani siswa putra dan putri di SMP Cahaya Pengharapan Abadi;

2) Untuk mengetahui Manakah diantara siswa/i tersebut yang memiliki tingkat kesegaran jasmani yang lebih baik; 
Dalam penelitian ini hanya membahas tentang tingkat kesegaran jasmani pada siswa SMP Cahaya Pengaharapan Abadi.

\section{METODE}

Jenis penelitian yang digunakan adalah kuantitatif dengan menggunakan metode penelitian deskriptif analisis. Penelitian deskriptif adalah suatu metode penelitian yang ditujukan untuk menggambarkan fenomena-fenomena yang ada, yang berlangsung pada saat ini atau saat yang lampau. Pendekatan deskriptif ini menggambarkan kesegaran jasmani yang ada pada siswa SMP Cahaya Pengharapan Abadi. Penelitian ini tidak mengadakan manipulasi atau pengubahan pada variabel-variabel bebas, tetapi menggambarkan suatu kondisi apa adanya. Penggambaran kondisi bisa individual atau kelompok, dan menggunakan angka-angka (Sukmadinata, 2005:53-54).

Penelitian ini dilakukan di SMP Cahaya Pengharapan Abadi Labuhan Deli. Subjek penelitian ini adalah siswa putra dan putri SMP Cahaya Pengharapan Abadi yang duduk pada kelas IX di sekolah tersebut. Sampel yang diteliti usia 13-15 tahun dengan jumlah sampel siswa 11 putra dan 6 putri, Pengambilan sampel dalam penelitian ini menggunakan teknik random sampling. Adapun cara pengambilan sampel yaitu dari beberapa kelas tersebut di buat undian yang didalamnya tertulis nama kelas kemudian di undi, dan siswanya juga dibuat undian untuk memilih 11 siswa putra dan 6 siswa putri dari setiap kelas yang terpilih.

Dalam penelitian ini terdapat dua variabel yaitu:

(1) Variabel bebas: Siswa putra dan putri SMP Cahaya Pengharapan Abadi;

(2) Variabel Terikat : Tingkat Kesegaran Jasmani.

Pada penelitian ini menggunakan Tes Kesegaran Jasmani Indonesia (TKJI) untuk dapat mengetahui tingkat kesegaran jasmani Siswa putra dan putri kelas VIII SMP Cahaya Pengharapan Abadi, harus melakukan kelima butir tes secara beruntun sesuai dengan urutan butir tes (TKJI). Sedangkan waktu antara tes yang satu dengan yang berikutnya paling lama 3 menit. Tes tersebut antara lain : (1) Lari cepat 50 meter; (2) Gantung siku tekuk selama 60 detik; (3) Baring duduk 60 detik; (4) Loncat tegak; (5) Lari 1000 meter Untuk putra dan 800 Meter putri.

\section{HASIL DAN PEMBAHASAN}

Pada bab ini berisi tentang hasil penelitian, data peserta pengamatan dari penelitian yang telah saya lakukan. Maka akan saya uraikan tentang perbedaan Tingkat Kesegaran Jasmani Siswa-siswi SMP Cahaya Pengharapan Abadi Labuhan Deli dengan menggunakan tes TKJI. Deskripsi data berupa data yang di peroleh dari hasil penelitian yang di lakukan di sekolah SMP Cahaya Pengharapan Abadi tentang perbedaan tingkat kesegaran jasmani dengan jumlah sampel 11 siswa putra dan 7 siswa putri dari sekolah.

Hasil Tes TKJI

\begin{tabular}{|l|c|c|c|c|c|c|}
\hline Nama Siswa & Jenis kelamin & Tes 1 & Tes 2 & Tes 3 & Tes 4 & Tes 5 \\
\hline Alvin & Laki-laki & 7.17 detik & 5 & 38 & $37.67 \mathrm{~cm}$ & 6.05 detik \\
\hline Nicolas & Laki-laki & 7.18 detik & 1 & 32 & $36.01 \mathrm{~cm}$ & 6.38 detik \\
\hline Karina & Perempuan & 8.10 detik & 28.15 detik & 24 & $30.10 \mathrm{~cm}$ & 5.58 detik \\
\hline Johtiya & Perempuan & 8.16 detik & 29.12 detik & 26 & $27.40 \mathrm{~cm}$ & 6.15 detik \\
\hline Blasius & Laki-laki & 7.77 detik & 1 & 32 & $37.80 \mathrm{~cm}$ & 6.12 detik \\
\hline Desmon & Laki-laki & 7.77 detik & 1 & 31 & $37.82 \mathrm{~cm}$ & 6.40 detik \\
\hline Christian & Laki-laki & 7.80 detik & 3 & 35 & $37.73 \mathrm{~cm}$ & 6.03 detik \\
\hline Erika & Perempuan & 8.08 detik & 27.28 detik & 27 & $28.79 \mathrm{~cm}$ & 6.02 detik \\
\hline Sry & Perempuan & 8.14 detik & 30.15 detik & 28 & $29.80 \mathrm{~cm}$ & 5.60 detik \\
\hline Roy & Laki-laki & 7.60 detik & 6 & 30 & $37.79 \mathrm{~cm}$ & 6.08 detik \\
\hline Ricky & Laki-laki & 7.65 detik & 5 & 32 & $38.79 \mathrm{~cm}$ & 6.10 menit \\
\hline Randy & Laki-laki & 7.77 detik & 8 & 33 & $37.76 \mathrm{~cm}$ & $5.90 \mathrm{menit}$ \\
\hline Rendy & Laki-laki & 7.79 detik & 7 & 32 & $39.07 \mathrm{~cm}$ & 5.79 menit \\
\hline Indah & Perempuan & 8.19 detik & 29.28 detik & 25 & $25.80 \mathrm{~cm}$ & 6.18 detik \\
\hline Benedit & Laki-laki & 7.87 detik & 6 & 30 & $36.03 \mathrm{~cm}$ & 5.75 menit \\
\hline
\end{tabular}

Dipublikasikan Oleh :

UPT Publikasi dan Pengelolaan Jurnal

Universitas Islam Kalimantan Muhammad Arsyad Al-Banjari Banjarmasin 


\begin{tabular}{|l|c|c|c|c|c|c|}
\hline Darwis & Laki-laki & 7,10 detik & 8 & 40 & $40.12 \mathrm{~cm}$ & 5.51 menit \\
\hline Feronika & Perempuan & 8.20 detik & 28.90 detik & 26 & $25.50 \mathrm{~cm}$ & 6.28 detik \\
\hline
\end{tabular}

$\mathrm{N}=$ Jumlah Siswa

$\mathrm{JK}=$ jenis kelamin

$\mathrm{T} 1=$ Tes lari 50 Meter

$\mathrm{T} 2=$ Tes Pull $U p$

T3= Tes Sit $U p$

T4= Tes Vertical Jump

T5= Tes Lari 800 Meter (putri) dan 1000 Meter (Putra)

\section{PENUTUP}

\section{Kesimpulan}

Simpulan Berdasarkan hasil peneltian dan pembahasan maka dapat diambil kesimpulan bahwa tingkat kesegaran jasmani siswa/i kelas VIII SMP Cahaya Pengharapan Abadi diperoleh hasil penelitian rata-rata TKJI SMP Cahaya Pengharapan Abadi adalah lari 50 meter putera rata-rata 7.10 detik dan puteri 8,08 detik. Gantung siku tekuk putera rata-rata 8 kali dan puteri 30.15 detik. Sit-Up putera rata-rata 40 kali dan puteri 28 kali. Vertical Jump putera rata-rata $40.12 \mathrm{~cm}$ dan puteri $30.10 \mathrm{~cm}$. Lari 1000 meter putera rata-rata 5 menit 51 detik dan $800 \mathrm{~m}$ puteri 5 menit 58 detik.

\section{Saran}

Berdasarkan hasil kesimpulan di atas maka dapat diambil kesimpulan sebagai berikut: Perlunya penambahan jam pelajaran pendidikan jasmani kesehatan bagi anak khususnya pada tingkat SMP karena dengan jumlah jam pelajaran 2 × 40 menit setiap minggu, maka perlu dilakukan penambahan jam pelajaran pendidikan jasmani dan kesehatan untuk meningkatkan tingkat kesegaran siswa. Sedangkan untuk memperoleh tingkat kesegaran jasmani yang lebih baik tentunya diperlukan latihan secara rutin dan terprogram.

Jika guru pendidikan jasmani, olahraga dan kesehatan hanya mengandalkan jam pelajaran saja 74 untuk memperoleh tingkat kesegaran jasmani pada siswa, tentunya waktu yang tersedia tidak memungkinkan untuk mencapainya. Maka guru pendidikan jasmani, olahraga dan kesehatan berupaya semaksimal mungkin untuk mencari terobosan-teroboan untuk dapat meningkatkan tingkat kesegaran jasmani anak.

Perlu adanya alternatif baru bagi guru Pendidikan jasmani oralharag dan keseharan untuk meningkatkan tingkat kesegaran jasmani bagi siswa. Hal ini dapat dilakukan dengan cara memberikan tambahan kegiatan pada sore hari bagi dalam bentuk kegiatan ekstrakurikuler maupun intrakurikuler, dengan penambahan jam latihan tersebut diharapkan dapat meningkatkan tingkat kesegaran jasmani bagi anak-anak.

Dipublikasikan Oleh :

UPT Publikasi dan Pengelolaan Jurnal

Universitas Islam Kalimantan Muhammad Arsyad Al-Banjari Banjarmasin 


\section{REFERENSI}

Kemdikbud. Buku pegangan Guru Pendidikan Jasmani Olahraga dan Kesehatan.Jakarta: Bumi Aksara. 2014.

Kemdikbud. Pendidikan Jasmani, Olahraga, dan Kesehatan. Edisi I. Jakarta: 2014

Suharsimi Arikunto, Suharjono dan Supandi. Penelitian Tindakan Kelas. Jakarta: Bumi Aksara, 2010.

Rahayu, Ega Trisna Strategi pembelajaran pendidikan jasmani. (Bandung: Alfabeta. 2013).

Rosdiani, Dini, Perencanaan Pembelajaran dalam Pendidikan Pasmani dan Kesehatan. Bandung: Alfabeta, 2013

Samsudin S. Perencanaan Pembelajaran Pendidikan Jasmani dan Olahraga. Universitas Negeri Medan, 2010.

Samsudin. Kurikulum Pendidikan Jasmani, Olahraga \& Kesehatan. Jakarta: POR PPs UNJ, 2012.

Sukmadinata, NS. 2005. Metode Penelitian Pendidikan. Bandung PT Remaja Rosdakarya

Tangkudung, James."Kepelatihan Olahraga”. Jakarta: Cerdas Jaya, 2012

Tilaar, HAR, Standarisasi Pendidikan Nasional, Jakarta: Rineka Cipta, 2006

Dipublikasikan Oleh: 